\title{
Gender norms and the gendered distribution of total work in Latin American households
}

\begin{abstract}
:
In this paper, we use time-use survey data for Mexico (2009), Peru (2010), and Ecuador (2012) to analyze differences between countries in terms of the gender distribution of total work. We explore whether the variation in the total time worked by women and men, and particularly, the gender gap unfavorable to women, are explained by substantive country differences, and specifically differences in gendered social norms. Using data from the World Values Survey (WVS) we compute a gender norms index aimed at measuring cross-country differences in gender norms, and find that more egalitarian countries exhibit higher levels of equality in the gender distribution of total work.
\end{abstract}

Keywords: Time use, Mexico, Peru, Ecuador, gender differences, gender norms.

JEL Codes: D13, J0, Z13 


\section{Introduction}

The recent development of time use surveys has allowed for in-depth analyses of the time allocation decisions of individuals and its determinants (Mark Aguiar and Erik Hurst 2007; Jose I. Gimenez-Nadal and Almudena Sevilla 2012). An increasing number of countries are now carrying out these surveys, and a commonality, independent of country characteristics, is that women in general devote relatively more time to unpaid domestic work than do men (Emily Esplen 2009). Furthermore, women specialize in household tasks and the care of others, concentrating on routine and more timeintensive unpaid work (Almudena Sevilla, Jose I. Gimenez-Nadal and Cristina Fernandez 2010; Shoshana A. Grossbard, Jose I. Gimenez-Nadal, and Jose A. Molina 2014).

A number of studies have focused on the determinants of time allocation in Latin American countries (Constance Newman 2002; Marcelo Medeiros, Rafael G. Osório, and Joana Costa 2007; Vivan Milosavljevic 2007; Esplen, 2009; Sarah Gammage 2010; Carla Canelas and Silvia Salazar 2014; Analia Calero, Rocío Dellavalle, and Carolina Zanino 2016). If we define total work as the sum of the time devoted to paid work, unpaid domestic work, child care, and other care - where "paid work" refers to all the activities that directly result in income (wage employment, self-employed, etc.) - these studies show that the total time worked by women always exceeds that worked by men. For instance, Canelas and Salazar (2014) find that women in Bolivia, Ecuador, and Guatemala devote more time to total work than men in these three countries. Newman (2002) finds that the time devoted to total work by men is 80 percent lower than the total work of women in two urban areas of Ecuador. Medeiros, Osório, and Costa (2007) analyze inequalities in time use among urban Bolivian adults, and find that despite there being a trade-off between paid and unpaid work, this trade-off is only partial since women's participation in the labor market tends to result in a double shift of paid and unpaid work.

One thing that stands out in existing studies is that the total time devoted by both men and women to paid and unpaid work varies significantly across countries. The variation in the total time worked across countries could be due to the different methodologies employed in these surveys, or to substantive differences among particular countries. In this paper analyzing time use data from Mexico (2009), Peru 
(2010), and Ecuador (2012), we explore whether the variation in the total time worked by women and men, and particularly, the gender gap unfavorable to women, is explained by substantive country differences, and specifically, differences in gendered social norms.

Gender norms may be thought of as a coordinating device between the total work of men and women within households: they may also encourage an inegalitarian distribution of time between men and women in terms of total work (Michael Burda, Daniel S. Hamermesh, and Philippe Weil 2013). Gender norms refer to the factors that result in less flexibility among men with regard to participation in household production and caring activities, as men often do not share the unpaid domestic work when their partners are also in the labor market, which translates into unequal total work. As argued by Sevilla, Gimenez-Nadal and Fernandez (2010), there exist norms of masculinity, in the sense that men may feel certain tasks undermine their status, and norms of femininity, as women may insist on caring for others due to their own internalized sense of self-worth. While such norms may generate household they imposes costs and substantial limitations on the women of the family. More traditional gender norms dictate that women bear the heaviest burden of total work, which, in turn, may act as drag on economic development.

Using the last wave of the World Values Survey (WVS, 2010-2014), we create a "gender norms" index aimed at measuring cross-country differences in gender norms. We identify the effect of "gender norms" on gender differences in total work by considering cross-country variations in the index (Almudena Sevilla 2010; Jose Ignacio Gimenez-Nadal, Alberto Molina and Almudena Sevilla 2012).We find that, when crosscountry differences in gender norms are taken into account, differences in gender norms are able to explain part of the gender gap in total work observed. In countries with more egalitarian gender norms, the gender gap in total work is narrower, and thus crosscountry differences in the gender distribution of household labor may be partly explained by cross-country differences in gender norms. We take into account countryvariant factors, such as the growth rate of GDP and total fertility rates, and find that they are also relevant in determining the time devoted to total work.

Our contribution to the literature is three-fold. First, we contribute to the analysis of gender differences in the uses of time in a comparative framework for three Latin American countries. While gender differences in time use in each of the three countries 
have been previously studied (INEI 2011; INEC 2012; INEGI 2014), cross-country differences have yet to be analyzed. Second, we contribute to the study of gender norms and their effects on the time-allocation decisions of individuals. Despite prior research on this topic, the contributions to date have focused on single countries, with an emphasis on developed countries. The comparison of gender norms across countries may be helpful in identifying their specific effects, and guide the development of policies aimed at reducing gender inequality and household poverty.

Third, the analysis of how individuals allocate their time is important, since gender differences may have implications for individual and household well-being (Daniel Kahneman and Alan B. Krueger 2006; Jose I. Gimenez-Nadal and Jose A. Molina 2015). The unpaid work obligations of women seem to negatively affect their labor supply, and sometimes lead to poorer education and economic outcomes for women (Rania Antonopoulos and Indira Hirway 2009). However, unpaid work is also productive, as it provides services to the household, and is essential for family welfare. Thus, if the role of the state is unchanged the focus should be on the redistribution of unpaid work between men and women, rather than on its reduction, with men taking on household responsibilities when women access the labor market. This is an important point, because a reduction in overall unpaid work may not require normative change, while redistribution almost certainly does, justifying a focus on the relationship between gender norms and total time worked.

\section{Background}

Over the past three decades, one of the most significant changes in Latin America has been the growing economic contribution of women, due mainly to millions of women having entered the labour market. The female labor force participation rate in countries of Latin America and the Caribbean has grown from 33.7 percent in 1990 to 41.5 percent in 2014 (CEPAL 2014; World Bank 2016), which is consistent with the increase in the education of women (CEPAL 2014). Despite this increase, specialization within the household has changed very little, and women continue to do most of the unpaid labor, particularly domestic and care labor. This is the case in Ecuador (Newman 2002; INEC 2012; Canelas and Salazar 2014), Bolivia (Medeiros, Osório and Costa 2007; Canelas and Salazar 2014), Guatemala (Canelas and Salazar 2014), Nicaragua 
(Mercedes Aguilar, Isolda Espinosa, and Javier Argeñal 2004; Valeria Esquivel, Debbie Budlender, Nancy Folbre, and Indira Hirway 2008), Mexico (INEGI 2014), Peru (INEI 2011), and Argentina (Valeria Esquivel 2010), among others.

Of special relevance in the observed gender differences in the time devoted by men and women to paid and unpaid work is the care of others. Researchers have given increased emphasis in recent years to what has been termed the "care economy" Analyses of the time devoted to caring for others - children, the sick, the disabled, and the elderly - have become very important from a policy perspective. Greta Friedemann-Sanchez and Joan M. Griffin (2011) argue that unpaid care-giving must be analyzed separately from domestic tasks. Esplen (2009) offers a review of the state of care-giving in the global south, and how it interacts with paid labor. The author considers that the care of others is important because affects individual lives, it creates and reinforces gender inequalities, and it is linked to poverty and lack of well-being.

Gender norms are among the factors that may help to explain the existence of gender differences in the time devoted to paid and unpaid work, including the care of others. Dana V. Hiller and William W. Philliber (1986), Yoshinori Kamo (1988), and Sampson Lee Blair and Daniel T. Lichter (1991) find a negative relationship between traditional beliefs and unpaid work. Analyses of gender norms consider that peer pressure to conform to a common norm of time allocation makes time- use patterns more similar, or not, between men and women. Further, gender norms are not static, and may change over time in response to broader processes of socio-economic change and from the dynamics of gender relations themselves (Rebeca Pearse and Raewyn Connell 2016). As argued by Bina Agarwal (1997), gender norms affect the bargaining over time allocation, and this bargaining process may itself affect gender norms. Gender norms set limits on what can be bargained over, they are a determinant of, or constraint on, bargaining power, they affect how the process of bargaining is conducted, and they constitute a factor to be bargained over.

Sevilla, Gimenez-Nadal and Fernandez (2010) discuss possible explanations of why men and women specialize in certain types of tasks in housework and childcare in the case of Spain, and consider the norms of masculinity and femininity. Men are often particularly resistant to doing household chores that directly attend to the needs of

\footnotetext{
${ }^{1}$ The "care economy" includes both paid and unpaid labor, and refers to the fact that women, when they do work for pay, are in 'caring labor" (health, education, domestic servants, etc.).
} 
women and children, such as washing and ironing clothes of family members, although activities of a more general character, such as cooking, mopping the floor, and running errands, can occasionally be taken on by men. The less visible, more mundane, and often dirtiest work continues to be carried out by women (Patrick Welsh 2001). This argument may be used to explain why caring activities in Latin American are the domain of women exclusively (Esplen 2009). Men may see caring activities as an affront to their dignity, with a widespread perception of women as "natural carers", which deters men from providing care. In this sense, men's resistance to more active involvement in care and domestic tasks is driven by deeply-held gender norms that create social barriers to men assuming care-giving roles (Dean Peacock 2003).

\section{Data: time use surveys}

For our empirical analysis, we use the information from the time use surveys for Mexico (2009), Peru (2010) and Ecuador (2012). Time use surveys are a fundamental tool for understanding gender inequalities and role reproduction, through data showing the inequitable distribution of time allocated to paid and unpaid work, as well as the availability of time women and men for other daily activities (Karina Batthyány. 2015). The methodologies employed were defined by the institutes of statistics of each country: INEGI in Mexico, INEI in Peru, and from INEC in Ecuador. The targeted population in each is all members of the household over age 12. The three surveys take as reference period the previous week. ${ }^{2}$

Each of the surveys use a list of pre-coded activities. A limitation is that none of them allow for the consideration of simultaneous or "secondary" activities. The incorporation of such activities usually increases the total amount of time dedicated to household production and is also important in gender comparisons, given that there may be gender differences in the ability to carry out, and need for, multitasking (Charlene M. Kalenkoski and Gigi Foster 2015, 2016). Thus, the consideration of secondary activities could change the conclusions obtained in this paper (Esquivel 2010). ${ }^{3}$

\footnotetext{
${ }^{2}$ More information on the technical aspects of the surveys, including their coverage and representativeness, can be found at the corresponding statistical agencies.

${ }^{3}$ See Esquivel et al. (2008) for a review of the inclusion of simultaneous activities in the diaries, and measurement issues of these simultaneous activities. Other methodological issues, such as the inclusion of a time-use survey as a module in an ongoing household survey, the use of an activity-diary instead of a task-list classification, the consideration of simultaneous activities, or the statistical significance of time use estimates, are described in Esquivel
} 
Regarding the comparability of time use surveys in Latin America there is still no common standardized classification of activities, among countries as each follows a different protocol in the coding of activities, adapting different protocols to their own situations. The lists of activities are ICATUS (Clasificación Internacional de Actividades para Estadísticas sobre el Uso del Tiempo) in Peru, CMAUT (Clasificación Mexicana de Actividades de Uso del Tiempo) for Mexico, and CAUTAL (Clasificación de Actividades sobre Uso del Tiempo para América Latina y Caribe) in Ecuador. Nonetheless the structure of ICATUS provides the benchmark for CMAUT and CAUTAL. Since most of our analysis is based on the comparison of broad classifications of activities rather than their detailed disaggregation, we consider that we can draw meaningful comparisons across countries.

For purposes of comparison with prior studies, we restrict our sample to individuals between 21 and 65 years of age, who are not students or retirees. We use the demographic weights proposed by Lawrence F. Katz and Kevin M. Murphy (1992). ${ }^{4}$ We define total work as the sum of the time devoted to paid work, unpaid (domestic) work, child care, and other care. It is important to distinguish between unpaid (domestic) work, child care, and other care, since, as pointed out by Juan C. Campaña, Jose I. Gimenez-Nadal and Jose A. Molina (2016), those women who have a better position in the labor market, rather than reduce their time dedicated to the care of children in the home, increase it in the three countries. We include a separate category for the care of others, given its importance in creating gender differences in time allocation decisions. All the time devoted to these different categories is measured in hours per week. Paid work includes all the time spent working in the paid sector, including main job, a second job where applicable, and overtime, including paid work at home and travel allowances, etc. Unpaid domestic work - henceforth shortened to unpaid work includes any time spent in the preparation of meals, cleaning, laundry, vacuuming, maintenance, time spent on the procurement of goods and services, outdoor cleaning and vehicle repair, among others. Child care includes all the time spent on child care as

(2010). Despite that cross-country differences in unpaid domestic work, child care, and other care may reflect methodological differences in terms of instruments, classification schemes, and age groups covered, among others, Debbie Budlender (2010) argues that such differences cannot explain away more than a small proportion of the differences, and thus comparability across surveys is still valid.

\footnotetext{
${ }^{4}$ The reference country is Ecuador. See Online Appendix A for further explanation of the demographic weights, and see Table A1 for a description of the demographic characteristics of the samples. The demographic weights are used to allow for a proportional representation of individuals in the three countries..
} 
a main activity. Other care includes the time devoted to the care of others, which includes non-household children, and household and non-household adults. ${ }^{5}$

\section{Empirical evidence}

Table 1 presents the time devoted to paid work, unpaid work, childcare, other care, and total work by men and women in Mexico, Peru, and Ecuador. The difference between women and men in the time devoted to the category, and the p-value of the difference are shown in the last two columns. A negative difference indicates that women in that country devote comparatively more time to this activity than men. The p-value is based on a t-test type of equality of means.

Regarding the time devoted to paid work, there is a gender difference in favor of men since they devote 28.95, 27.57, and 27.92 more hours per week in Peru, Mexico, and Ecuador, respectively than women to paid work. Regarding the time devoted to unpaid work, there is a gender difference of 25.84, 26.44, and 28.92 more hours per week in favor of women in Peru, Mexico, and Ecuador, respectively. For child care the gender difference in favor of women is 3.78, 4.25 and 5.12 hours per week in Peru, Mexico, and Ecuador, respectively. Considering other care women devote 0.99, 0.54, and 1.23 more hours per week than men in Peru, Mexico, and Ecuador, respectively. Finally, for total work, women devote 1.66, 3.67, and 7.34 more hours per week in Peru, Mexico, and Ecuador, respectively. Thus, women devote more time to total work than men in the three countries.

\section{Gender norms: The World Value Surveys}

To analyze how gender norms influence the distribution of total work, we construct a gender norms index to measure the degree of equality that is observed in each country, using the data from the World Values Survey (WVS), The WVS consists of nationally representative surveys conducted in almost 100 countries with a set of common

\footnotetext{
${ }^{5}$ See Appendix B for a description of all the activities included in each time use category. One important limitation of the surveys is that they do not include information on secondary activities, or who else is present during the activity, information that has been shown to be important in the computation of the total time spent with children (Sevilla, Gimenez-Nadal and Fernandez 2010). A recent estimate by Shira Offer (2014) reveals that only about one-quarter of all time with children is spent in direct interaction.
} 
questionnaires. The survey has six waves, and we choose the period 2010-2014, as the time use surveys used here correspond to this period.

To be consistent in our sample selection, we construct the gender norms index using individuals between 21 and 65 years of age, who are not students or retired. Given that we have information on the geographical location of the individuals, we can match responses of respondents from the WVS to respondents of the time use surveys according to their region of residence. We utilize five questions from a section of the survey concerning opinions regarding the roles of women in society, with the answers to these questions scaled as 1 (strongly agree), 2 (agree), 3 (disagree), and 4 (strongly disagree). We use the following questions: 1) When a mother works for pay, the children suffer; 2) On the whole, men make better political leaders than women do; 3) A university education is more important for a boy than for a girl; 4) On the whole men, make better business executives than women; 5) Being a housewife is just as fulfilling as working for pay.

In order to combine several questions into one index, we follow the work of Sevilla (2010), and Jose M. Fernandez-Crehuet, Jose I. Gimenez-Nadal, and Luisa E. ReyesRecio (2016), and use the Principal Component Analysis (PCA) technique. We consider all respondents of the WVS in the three countries and apply the PCA technique. From this analysis, we extract the first principal component, and from that we use the factor loadings as weights for the questions. Hence, the weights assigned to each question are 0.25 to question (1), 0.55 to question (2), 0.54 to question (3), 0.56 to question (4), and 0.20 to question $(5) .{ }^{6}$ When we apply these weights to the questions selected, we obtain a value for each respondent in the WVS. Table 2 shows the average values obtained for each question (attitudes) for both men and women in the three countries. ${ }^{7}$ Regarding the interpretation of the gender norms index, the value 1 corresponds to traditional gender norms associated with the "male breadwinner/female housewife" model, and the value 4

\footnotetext{
${ }^{6}$ As robustness checks, we change the way we build the gender norms index to test for the validity of our results. Results are shown in Online Appendix Table C8, and are consistent with our main results. It is interesting that, on questions 2, 3, and 4, the values for women exceed those for men, suggesting that women are less 'traditional' and more likely to see women in non-traditional roles than are men. But on questions 1 and 5, which have to do with women's roles, the mean for men exceeds that for women. Thus, it may seem that questions 1 and 5 are related to gender roles in a different way than questions 2,3 , and 4 . This may explain why the relative weights given to questions 1 and 5 are comparatively lower than weights given to questions 2,3 , and 4 . Results excluding these questions from the gender roles index (Table C8) are consistent with our main results.

${ }^{7}$ The fact that the average values of the attitudes vary between men and women is common even in the most egalitarian countries. Arlie R. Hochschild (1989) shows that, although men and women show equal behavior, men are more likely than women to embrace traditional values.
} 
is related to either neutral or more egalitarian gender norms. Thus, higher values of the gender norms index are interpreted as evidence of more egalitarian gender norms. From the analysis, it appears that individuals from Ecuador present a higher degree of agreement with the statements analyzed, and thus should present less egalitarian gender norms compared to individuals from Peru who show a lower agreement with the statements.

Regarding the relationship between the gender norms index, and the gender differences in total work, we observe that those countries with higher values of the gender norms index present lower values of the gender gap in total work. In fact, when at the country level we consider the correlation between the values of the gender gap in total work, and the average values of the gender norms index, the correlation coefficient is -0.89 , showing a negative correlation between the gender norms index and the gender gap in total work. However, this raw correlation cannot be interpreted causally, as other factors may be affecting the gender gap in total work.

\section{Econometric strategy}

We estimate the regressions of the time dedicated to total work using Ordinary Least Squares (OLS) models. We estimate the following model:

$$
T_{i k}=\alpha+\beta_{1} \text { Woman }_{i k}+\beta_{2} x_{i k}+\beta_{3} Z_{k}+\beta_{4} I_{k}+\varepsilon_{i k}
$$

where $T_{i k}$ is the time spent in total work by individual "i" in country "k";Woman ${ }_{i k}$ takes value " 1 " if respondent " $\mathrm{i}$ " in country " $\mathrm{k}$ " is female, and " 0 " otherwise; $x_{i k}$ is a vector of socio-demographic characteristics that includes primary education, university education (secondary education as reference), age, age squared, number of household members, number of children in the household (aged 0 to 4 years, aged 5 to 12 years, aged 13 to 17 years), number of household members aged 70 and over, the presence of a partner, the number of men and women participating in the labor market in the household, whether the household lives in a rural area or not, and whether the respondent is indigenous or not. $Z_{k}$ represents country-specific factors, $I_{k}$ represents dummy variables of the countries (with Ecuador as reference), and $\varepsilon_{i k}$ is the error term. The dummy variable Woman $_{i k}$ is included to measure gender differences among countries. $\beta_{1}>0$ indicates that women spend more time in total work than do men. Prior studies have shown the importance of controlling for characteristics such as age, 
education, race or ethnic origin, the size and structure of the household, and the urban or rural status of respondents(Jose I. Gimenez-Nadal and Jose A. Molina 2013; GimenezNadal and Sevilla 2014; Grossbard, Gimenez-Nadal and Molina 2014). ${ }^{8}$ Country fixed effects (ref.: Ecuador) are also included in our regressions to control for unmeasured factors that may influence the time devoted by men and women to total work.

We include specific country-variant factors in order to measure variables that may potentially affect the time devoted to total work by individuals. These factors (measured over the appropriate three-year period for each country) include: the annual average growth rate of GDP per capita, female labor force participation rates, masculinity ratios, total fertility rates, and an indicator of the population aged 65 and older in the country. Regarding the inclusion of the growth of GDP per capita of the country, Naila Kabeer's (2016) review of prior studies finds quite robust evidence that gender equality has a positive impact on economic growth, although findings analyzing the impact of economic growth on gender equality are far less consistent. In this sense, economic growth may have a positive, negative, or null impact on gender equality. To the extent that the gender gap in total work is related to gender equality, we consider it important to include the growth rate of GDP per capita in our analysis of the gender gap in total work

The national female labor force participation rate may also be important in explaining gender differences in the time devoted to total work if less traditional countries have higher female labor force participation rates, encouraging women to participate more in the labor market. Such higher participation may add an extra burden on them, however adding paid work time to their unpaid and caring responsibilities and increasing the gender gap in total work. Nonetheless, it could be that in countries with higher female labor force participation rates, women simply substitute paid work time for unpaid and care time, and the gender gap in total work remains unchanged. A priori, we cannot hypothesize whether the relationship between the gender difference in total

\footnotetext{
${ }^{8}$ See Online Appendix Table $\mathrm{C} 1$ for a description of the socio-demographic and household characteristics of individuals in the three countries. Online Appendix C (Table C2 and Table C3) shows the time devoted by men and women to paid work, unpaid work, child care, other care, and total work, considering whether men and women are in a couple (married and cohabiting) or not. We find that gender differences in total work are much greater when women do not have a partner in the case of Mexico and Ecuador. Online Appendix C (Table C4 and Table C5) shows the time devoted by men and women to the different activities, considering the presence or not of children under 18 in the household. The gender differences in total work are accentuated by the presence of children in the home, particularly in the case of Ecuador.
} 
work and the female labor force participation rate is positive, negative, or null. Gender ratios have been found to be an important factor in the value of women in the marriage market, and thus an important factor in the determination of the time devoted to market and unpaid work (Catalina Amuedo-Dorantes and Shoshana Grossbard 2007; Grossbard, Gimenez-Nadal and Molina 2014). In countries where women are relatively scarce compared to men, the gender gap in total work is expected to be lower. We measure masculinity ratios, defined as the number of men per 100 women in the region of residence.

The number of children is important in determining the time men and women devote to total work, as children add child care responsibilities, normally supported by women (Peacook, 2003; Esplen, 2009; Gimenez-Nadal and Sevilla 2014). In countries with higher fertility rates, the time devoted to total work is expected to be higher, relative to countries with lower fertility rates, and it is also expected that higher fertility rates are associated with more time in total work for women, given that in these countries child care time falls almost entirely on women. Thus, we would expect a positive relationship between the total fertility rates and women's time devoted to total work. Finally, we include a measure of the population aged 65 and older in the country of reference. The idea is to use a measure of what Budlender (2010) defines as the care dependency ratio, an indicator of care demand, defined as the population aged 65 and older as a percentage of the total population of the country. In countries with a higher dependency ratio, the need for care may be higher, which affects the time devoted to total work by women, as care responsibilities fall almost entirely on women. Thus, higher dependency ratios may increase the gender gap in total work.

Table 3 shows average values of the country-level variables. The highest level of average annual growth of GDP per capita is for Peru (4.90), as is the highest rate of female labor force participation (66.87). Masculinity ratios range from 96.08 in Mexico to 100.56 in Peru. Total fertility rates are comparatively higher in Ecuador (2.63), and the dependency ratio ranges from 5.67 in Mexico to 6.10 in Peru. When we compute the cross-country correlation between the gender gap in total work, and the selected country-variant factors, we find that the correlation coefficients are $0.4695,0.0826$, $0.4385,0.3615$ and 0.3453 for the growth of GDP per capita (annual), female labor force participation rates, masculinity ratios, total fertility rates, and population aged 65 
and older, respectively. Thus, the greatest correlation with the gender gap is the relationship between the growth of GDP per capita (annual) and the masculinity ratio.

\section{Results}

Column 1 of Table 4 shows the results of the estimation of equation (1), without considering country-specific factors, and with men being the reference category. We see that $\beta_{1}$ is positive and statistically significant at standard levels, indicating that women devote 3.92 more hours per week to these activities controlling only for sociodemographic and country fixed effects. Columns 2 to 6 of Table 4 introduce the country-variant factors described above. While all variables have coefficients that are statistically significant, the coefficient measuring gender differences in total work does not significantly change in comparison with the results shown in column 1 . Thus, while cross-country differences may help to explain differences in the time devoted to total work for men and women, we still find that women devote more time to total work than men. This conclusion does not change when we introduce country-variant factors at the same time in the regression (column 7).

To measure the effect of gender norms, Column 8 of Table 4 shows the results of including the gender norms index in the model, and we observe that the gender gap in total work is reduced almost by one-third. Specifically, the coefficient goes from 3.91 hours per week from Column (7) to 2.51 hours per week in column (8). The results in column 8 show that the gender norms index is positive and statistically significant, indicating that in countries with more egalitarian gender norms, men devote more time to total work, and thus the gender gap in total work is reduced.

Regarding country-variant factors, we find that a higher GDP growth rate, greater female labor force participation rate, higher total fertility rate and higher dependency ratio, all have a positive relationship with the time devoted to total work. On the contrary, higher masculinity ratios have a negative relationship with the time devoted to total work in the three countries.

Since we have time use information for both members of couple, in Table 5 we offer an alternative analysis focusing on the gender gap in total work among married/partnered men and women. When we pool all the couples together, we observe that the gender gap in total work (column (1)), is positive and statistically significant, 
which indicates that partnered women devote 3.50 more hours per week to total work than partnered men. Column (2) shows the results when we include the gender norms index, and we observe that the difference in total work between men and women is reduced by 1.1 hours per week. Again, the coefficient of the gender norms index is positive and statistically significant.

Most of the studies that have been undertaken by the Latin American statistical agencies show major differences in the time use of women who are employed versus those who do not participate in the labor market. Thus, the labor force participation of women may be important in determining the time devoted to total work, and thus the gender gap in total work. When we compare gender gaps in total work according to the labor force status of women living in a couple, we find (see Tables C6 and C7 of the Online Appendix) that, in couples where both members participate in the labor market, men devote less time to total work than do women, while in couples where men are in the labor force and women are not, men devote more time to total work than do women. Thus, the gender gap in total work depends crucially on the labor status of women.

Given this evidence, we have carried out the analysis comparing men and women living in couple according to their labor market participation. Columns (3) and (5) of Table 5 show the results of estimating Equation (1) when we restrict the sample to couples where both members are in the labor market (information obtained from selfreported labor force status and not by the survey measure of paid work), and to couples where men are in the labor force and women are not, respectively. The results described in the previous paragraph are confirmed. For the regression comparing couples where both members of the couple are in the labor market, we observe that there is a gender gap in total work unfavorable to women, as they devote 16.10 more hours per week to total work in comparison to men. On the other hand, when we analyze couples where men are in the labor force and women are not, men devote 6.92 more hours per week to total work.

When we introduce the gender norms index for these two sub-samples (columns (4) and (6) of Table 5), differences in total work between men and women are still significant, although their magnitudes are different (e.g., 15.75 hours for couples where both members work and -7.69 hours for couples where men are in the labor force and women are not). Regarding the results for couples where both members work, the difference in the time devoted to total work by women in comparison to men decreases by 21 minutes when we include the gender norms index in the regression. Regarding 
results for couples where men are in the labor force and women are not, the difference in the time devoted to total work by men in comparison to women increases by 46 minutes. In the specific case of working women who devote more time to total work than men, gender norms tending to more egalitarian roles help reduce the difference in total work. In the specific case of non-working women who devote less time to total work than men, gender norms tending to more egalitarian roles of men and women in the country seem to add more responsibilities to men regarding total work, which contribute to increase the gender gap favoring men in total work. All in all, our results point towards gender norms affecting the time men and women devote to total work, with more egalitarian gender norms adding responsibilities regarding total work to men.

\section{Conclusions}

In this study, we analyze the time allocation decisions of men and women in Mexico, Peru, and Ecuador. The results indicate that Ecuador has comparatively larger gender differences in the distribution of total work. To explain these gender differentials, we examine the influence of gender norms in each country by constructing a gender norms index using data from the World Values Survey (WVS). We find that those countries with more egalitarian gender norms present smaller gender differences in total work. Our results indicate that, when cross-country differences in gender norms are taken into account, such differences in gender norms are able to explain part of the gender gap in total work. We also find that macroeconomic conditions, such as the GDP growth rate, are related to gender inequality in total work, which raises questions about the place economic factors such as productivity, improvement of infrastructure, and employment policies have in the explanation of economic growth.

The analysis of the time allocation decisions of individuals is important in order to have a more complete view of individual well-being, given the limitations of GDP as a measurement of well-being and development (Nancy Folbre 2006). The fact that we find that generally women devote more time to total work than men in these countries may indicate that women have a lower level of well-being, particularly where both members of the couple are in the labor market. Family policies that challenge the existing gender structure, such as paternity leave may constitute a good starting-point for successfully shifting the household division of labor in a more egalitarian direction. 
(Ingela Björk 2004). Other strategies that can be used to foster a more egalitarian distribution of care activities include the implementation of public care centers (Naila Kabeer 2008; Shahra Razavi 2007), cash payments (Razavi 2007), and tax benefits and pensions (Daniel M. Gimenez 2005; Esplen, 2009).

The case of Ecuador, that presents somewhat of a paradox, since our comparative analysis shows that it has the largest absolute difference by gender in total work and presents relatively less egalitarian gender norms than either Peru or Mexico. These results contrast with other studies that show that Ecuador has a relatively gender egalitarian distribution of wealth, as around 52 percent of the gross household physical wealth is owned by women (Carmen D. Deere, Abena D. Oduro, Hema Swaminathan, and Cheryl Doss 2013). Among couples in Ecuador, the majority of major assets are owned jointly by the couple, rather than by men individually, and in the case of homeownership, joint ownership is more frequent in Ecuador than in other Latin American countries with similar marital and inheritance regimes (Carmen D. Deere and Jennifer Twyman 2012). This suggests that traditional social norms may not limit women's economic equality in all realms equally, but be particularly persistent in the case of unpaid domestic work and child care.

Our results also raise questions about the relationship between more egalitarian social norms and the persistence of intimate partner violence (IPV) against women. Sarah Bott, Alessandra Guedes, Mary Goodwin, and Jeniffer A. Mendoza (2012) show that Peru has a higher incidence of IPV than Ecuador, and a lower percentage of women who consider that wife-beating is justified. On the one hand, this could suggest that the questions included in the World Values Survey to measure gender norms are inadequate if they do not include questions regarding inegalitarian practices and values that are harmful to women. On the other hand, it could also imply that the gender norms index which we have constructed is best suited for explaining gender differences in total work compared to other indicators of gender inequality, a proposition which requires further study. Moreover, women's share of couple wealth is significantly associated with reducing the odds of physical violence against women in Ecuador, but so is the male breadwinner model where only the husband is employed compared to where both participate in the labor market, although it has a much smaller impact (Abena D. Oduro, Carmen D, Deere and Zachary Catanzarite 2015). Thus social norms may trail the gains that have been made in women's economic equality. 
Another limitation is that our data is a cross-section of individuals, and it does not allow us to identify differences in the time devoted to total work, net of (permanent) individual heterogeneity in preferences. At present no panels of time-use surveys are available. The data at hand also does not allow us to consider issues such as the quality or intensity of work. Maria S. Floro and Anant Pichetpongsa (2010) analyze the work intensity of Thai workers, and find that women workers experience a higher incidence of work intensity, and hence lower quality of life, compared to men. If we were able to analyze inequalities in the gender distribution of work, and also differences in how individuals experience this time, policy-makers would be able to design more effective programs and economic and social policies. Researchers have measured differences in daily experiences in the use of time (Kahneman and Krueger 2006; Rachel Connelly and Jean Kimmel 2015; Gimenez-Nadal and Molina 2015) in developed countries, which could be used as a guide to measure daily experiences in Latin American countries.

The inequality caused by stereotypes and gender roles is deeply rooted in individual and social consciousness and is resistant to change, which may make the redistribution of paid and unpaid work very difficult (Stephanie Seguino 2007). Inequitable gender norms in turn influence men's relationships with their families with far reaching implications, for example in the prevention and transmission of sexual diseases, contraceptive use, physical violence, parenting, and behavior in health issues (WHO 2003; Gary Barker 2007). To achieve gender equality, continuous efforts must be made to publicize the important role of men in the promotion of gender equality. This could be done through development programs, national and local policy debates, and in international forums (Alan Greig, Michael Kimmel, and James Lang 2000). Policies that allow women to combine care responsibilities with work seem to promote improvements in well-being, and to accelerate the dismantling of stereotypes and standards that harm women (Seguino 2007). Furthermore, making men aware of the existing problems in gender relations and how these affect their lives, is but a first step in challenging gender inequalities (Esplen 2009; Joyce C. Jacobsen 2006). Families, educational systems, religious institutions, communities, civil society organizations, development agencies and governments must all be involved in this process (Greig, Kimmel, and Lang 2000). 


\section{Disclosure statement}

No potential conflict of interest was reported by the authors.

\section{REFERENCES}

Agarwal, Bina. 1997. "Bargaining" and gender relations: Within and beyond the household." Feminist economics 3 (1): 1-51.

Aguiar, Mark, and Erik Hurst. 2007. "Measuring trends in leisure: The allocation of time over five decades." The Quarterly Journal of Economics 122(3): 969-1006.

Aguilar, Mercedes, Isolda Espinosa, and Javier Argeñal. 2004. Uso del Tiempo de los y las nicaragüenses. Programa MECOVI. Managua: Instituto Nacional de Estadísticas y Censos.

Amuedo-Dorantes, Catalina, and Shoshana Grossbard. 2007. "Cohort-level sex ratio effects on women's labor force participation." Review of Economics of the Household 5(3): 249-278.

Antonopoulos, Rania, and Indira Hirway. 2009. Unpaid Work and the Economy: Gender, Time Use and Poverty in Developing Countries. Palgrave Macmillan UK.

Barker, Gary. 2007 "Engaging men and boys in changing gender-based inequity in health." http://www.who.int/gender/documents/Engaging_men_boys.pdf

Batthyány, Karina. 2015. "Las políticas y el cuidado en América Latina: una mirada a las experiencias regionales." Naciones Unidas LC/L.3958

Björk, Ingela. 2004. "The Best Place for Mothers? Sweden." http://sciencecareers.sciencemag.org/career_development/previous_issues/articles/28 00/the_best_place_for_mothers

Blair, Sampson Lee, and Daniel T. Lichter. 1991. "Measuring the division of household labor gender segregation of housework among American couples."Journal of family issues 12 (1): 91-113.

Bott, Sarah, A. Guedes, M. Goodwin and J. A. Mendoza. 2012. "Summary Report," Violence against Women in Latin America and the Caribbean: A Comparative Analysis of Population-based Data from 12 Countries. Washington, D.C.: PAHO and Centers for Disease Control and Prevention, pp. 1-16

Budlender, Debbie. 2010. Time use studies and unpaid care work. New York: Routledge, 2010.

Burda, Michael, Daniel S. Hamermesh, and Philippe Weil. 2013." Total work and gender: facts and possible explanations". Journal of Population Economics 26(1): 239-261.

Calero, Analía, Rocío Dellavalle, and Carolina Zanino. 2016. Care economy in Argentina: Some results based on the Time use survey. Working Paper No. 72820, Munich, Germany: University Library of Munich.

Campaña, Juan C, Jose I. Gimenez-Nadal, and Jose A. Molina. 2016. "Increasing the Human Capital of Children in Latin American Countries: The Role of Parents' Time in Childcare." The Journal of Development Studies 1-21. 
Canelas, Carla, and Silvia Salazar. 2014. "Gender and ethnic inequalities in LAC countries." IZA Journal of Labor \& Development, 3, 18.

CEPAL. 2014. http://repositorio.cepal.org/bitstream/11362/37626/5/anexo_estadistico2014_es.zip(a ccessed September 2016).

Connelly, Rachel, and Jean Kimmel. 2015 "If You're Happy and You Know It: How Do Mothers and Fathers in the US Really Feel about Caring for Their Children?." Feminist Economics 21 (1): 1-34.

Deere, Carmen Diana, and Jennifer Twyman. 2012 "Asset ownership and egalitarian decision making in dual-headed households in Ecuador." Review of Radical Political Economics 44 (3): 313-320.

Deere, Carmen Diana, Abena D. Oduro, Hema Swaminathan, and Cheryl Doss. 2013. "Property rights and the gender distribution of wealth in Ecuador, Ghana and India." Journal of Economic Inequality 11(2): 249-265

Esquivel, Valeria. 2010. "Lessons from the Buenos Aires Time-Use Survey: A Methodological Assessment." In Rania Antonopoulos and Indira Hirway, eds. Unpaid Work and the Economy, pp. 181-214. Palgrave Macmillan UK.

Esquivel, Valeria, Debbie Budlender, Nancy Folbre, and Indira Hirway. 2008. "Explorations: Time-use surveys in the south." Feminist Economics 14 (3): 107-152.

Esplen, Emily. 2009. Gender and care: overview report. Brighton: Institute of Development Studies.

Fernandez-Crehuet, Jose M, Jose I. Gimenez-Nadal, and Luisa E. Reyes-Recio. 2016. "The National Work-Life Balance Index(C: The European Case." Social Indicators Research 128(1): 341-359

Floro, Maria S., and Anant Pichetpongsa. 2010. "Gender, work intensity, and wellbeing of Thai home-based workers." Feminist Economics 16 (3): 5-44.

Folbre, Nancy. 2006. "Measuring care: Gender, empowerment, and the care economy." Journal of human development 7(2): 183-199.

Friedemann-Sánchez, Greta, and Joan M. Griffin. 2011 "Defining the boundaries between unpaid labor and unpaid caregiving: review of the social and health sciences literature." Journal of Human Development and Capabilities 12 (4): 511-534.

Gammage, Sarah. 2010. "Time pressed and time poor: unpaid household work in Guatemala." Feminist Economics 16 (3): 79-112.

Gimenez, Daniel M. 2005. "Gender, pensions and social citizenship in Latin America," Vol. 46. United Nations Publications.

Gimenez-Nadal, Jose I, and Jose A. Molina. 2013. "Parents' education as a determinant of educational childcare time." Journal of Population Economics 26(2): 719-749.

Gimenez-Nadal, Jose I, and Jose A. Molina. 2015 "Voluntary activities and daily happiness in the United States." Economic Inquiry 53 (4): 1735-1750.

Gimenez-Nadal, Jose I, Almudena Sevilla and Jose A. Molina. 2012. "Social Norms, Partnerships and Children." Review of Economics of the Household 10(2): 215-236.

Gimenez-Nadal, Jose I, and Almudena Sevilla. 2012 "Trends in time allocation: A cross-country analysis." European Economic Review 56(6): 1338-1359. 
Gimenez-Nadal, Jose I, and Almudena Sevilla. 2014 "Total work time in Spain: evidence from time diary data." Applied Economics 46 (16): 1894-1909.

Greig, Alan, Michael Kimmel, and James Lang. 2000. "Men masculinities and development: broadening our work towards gender equality." Gender in Development Monograph Series, \#10, 1-19.

Grossbard, Shoshana. A, Jose I. Gimenez-Nadal, and Jose A. Molina. 2014. "Racial Intermarriage and Household Production." Review of Behavioral Economics 1 (4): 295-347.

Hiller, Dana V., and William W. Philliber. 1986 "The division of labor in contemporary marriage: Expectations, perceptions, and performance." Social Problems 33 (3): 191201.

Hochschild, Arlie R. (1989) The Second Shift. Avon Books.

INEC. Instituto Nacional de Estadística y Censo, (2012). "Encuesta de Uso del Tiempo: Presentación Principales Resultados," http://www.ecuadorencifras.gob.ec/documentos/webinec/Uso_Tiempo/Presentacion_\%20Principales_Resultados.pdf $\quad$ (accessed September 2016).

INEI. Instituto Nacional de Estadística e Informática, (2011). "Encuesta Nacional de Uso del Tiempo 2010: Principales Resultados," http://www.unfpa.org.pe/publicaciones/publicacionesperu/MIMDES-INEI-EncuestaNacional-Uso-Tiempo.pdf (accessed September 2016).

INEGI Instituto Nacional de Estadística y Geografía, (2014). "Uso del tiempo, una perspectiva estadística de género, 2009," https://www.gob.mx/cms/uploads/attachment/file/64926/Uso_del_tiempo.pdf (accessed September 2016).

Jacobsen, Joyce P. 2006. "Men's Issues in Development. In The Other Half of Gender," book (pp. 1-28) Washington, D.C.: The World Bank .

Kabeer, Naila. 2008. Mainstreaming gender in social protection for the informal economy, London: Commonwealth Secretariat.

Kabeer, Naila. 2016. "Gender equality, economic growth, and women's agency: the "Endless Variety" and "Monotonous Similarity" of patriarchal constraints." Feminist Economics 22 (1): 295-321.

Kahneman, Daniel, and Alan B. Krueger. 2006 "Developments in the measurement of subjective well-being." The journal of economic perspectives 20(1): 3-24.

Kalenkoski, Charlene M., and Gigi Foster. 2015. "Measuring the relative productivity of multitasking to sole-tasking in household production: experimental evidence." Applied Economics 47 (18): 1847-1862.

Kalenkoski, Charlene M., and Gigi Foster. 2016. "Are Women Better than Men at Multitasking Household Production Activities?." In Charlene M. Kalenkoski and Gigi Foster, eds, The Economics of Multitasking, pp. 19-32. Palgrave Macmillan US.

Kamo, Yoshinori. 1988. "Determinants of household division of labor resources, power, and ideology." Journal of family Issues 9 (2): 177-200.

Katz, Lawrence F. and Kevin M. Murphy. 1992. "Changes in relative wages, 19631987: supply and demand factors," Quarterly Journal of Economics 107(1): 35-78. 
Medeiros, Marcelo, Rafael G. Osório, and Joana Costa. 2007 "Gender inequalities in allocating time to paid and unpaid work: evidence from Bolivia." In Rania Antonopoulos and Indira Hirway pp, eds. Unpaid Work and the Economy, pp 58-75. Palgrave Macmillan UK, 2010.

Milosavljevic, Vivian. 2007. Estadísticas para la equidad de género: magnitudes y tendencias en América Latina. Cuadernos de la CEPAL 92. Publicación de las Naciones Unidas.

Newman, Constance. 2002 "Gender, time use, and change: the impact of the cut flower industry in Ecuador." The World Bank Economic Review 16(3): 375-395.

Oduro, Abena D., Carmen Diana Deere, and Zachary B. Catanzarite. 2015 "Women's wealth and intimate partner violence: insights from Ecuador and Ghana." Feminist Economics 21(2): 1-29.

Offer, Shira. 2014. "Time with children and employed parents' emotional well-being." Social science research 47: 192-203.

Peacock, Dean. 2003. "Men as partners: Promoting men's involvement in care and support activities for people living with HIV/AIDS." Expert paper prepared at 2003 for the Expert Group meeting of the United Nations, Division for the Advancement of Women on the role of men and boys in achieving gender equality.

Pearse, Rebecca, and Raewyn Connell. 2016. "Gender Norms and the Economy: Insights from Social Research." Feminist Economics 22(1): 30-53.

Razavi, Shahra. 2007. "The political and social economy of care in a development context: Conceptual issues, research questions and policy options". No. 3. United Nations Research Institute for Social Development

Seguino, Stephanie. 2007. "Plus Ça Change? 1 evidence on global trends in gender norms and stereotypes." Feminist Economics 13 (2): 1-28.

Sevilla, Almudena. 2010. "Household division of labor and cross-country differences in household formation rates." Journal of Population Economics 23(1): 225-249.

Sevilla, Almudena, Jose I. Gimenez-Nadal and Cristina Fernandez. 2010 "Gender roles and the division of unpaid work in Spanish households." Feminist Economics 16 (4): 137-184.

Welsh, Patrick. 2001. Men aren't from Mars: Unlearning machismo in Nicaragua. Catholic Institute for International Relations.

WHO (World Health Organization). 2003. "Integrating Gender into HIV/AIDS Programmes." Review Paper, WHO, Geneva.

World Bank. 2016. http://data.worldbank.org/indicator (accessed August 2016). 
Table 1.

Time devoted to paid work, unpaid work, child care, other care, and total work, by gender (hours per week)

\begin{tabular}{|c|c|c|c|c|c|}
\hline \multirow[b]{2}{*}{ Hours per week } & \multicolumn{2}{|c|}{ Women } & \multicolumn{2}{|r|}{ Men } & \multirow[b]{2}{*}{ Difference } \\
\hline & Mean & $\mathrm{SD}$ & Mean & $\mathrm{SD}$ & \\
\hline \multicolumn{6}{|l|}{ Paid work } \\
\hline Peru & 21.09 & $(24.32)$ & 50.04 & (19.91) & $-28.95 * * *$ \\
\hline Mexico & 20.25 & $(25.34)$ & 47.81 & $(23.91)$ & $-27.57 * * *$ \\
\hline Ecuador & 20.00 & $(24.22)$ & 47.92 & $(16.95)$ & $-27.92 * * *$ \\
\hline \multicolumn{6}{|l|}{ Unpaid work } \\
\hline Peru & 39.32 & (18.98) & 13.48 & $(11.29)$ & $25.84 * * *$ \\
\hline Mexico & 38.01 & $(20.29)$ & 11.56 & $(13.90)$ & $26.44 * * *$ \\
\hline Ecuador & 38.31 & $(20.48)$ & 9.39 & $(10.96)$ & $28.92 * * *$ \\
\hline \multicolumn{6}{|l|}{ Child care } \\
\hline Peru & 5.84 & $(7.98)$ & 2.07 & $(3.19)$ & $3.78 * * *$ \\
\hline Mexico & 5.92 & $(8.58)$ & 1.66 & $(3.56)$ & $4.25 * * *$ \\
\hline Ecuador & 6.76 & $(8.57)$ & 1.64 & $(3.59)$ & $5.12 * * *$ \\
\hline \multicolumn{6}{|l|}{ Other care } \\
\hline Peru & 1.63 & $(4.36)$ & 0.64 & $(2.27)$ & $0.99 * * *$ \\
\hline Mexico & 1.35 & $(4.90)$ & 0.81 & $(3.15)$ & $0.54 * * *$ \\
\hline Ecuador & 1.49 & $(6.80)$ & 0.27 & (1.81) & $1.23 * * *$ \\
\hline \multicolumn{6}{|l|}{$\underline{\text { Total work }}$} \\
\hline Peru & 67.89 & (19.87) & 66.23 & $(17.92)$ & $1.66^{* * *}$ \\
\hline Mexico & 65.52 & $(27.34)$ & 61.85 & $(23.04)$ & $3.67 * * *$ \\
\hline Ecuador & 66.56 & $(29.15)$ & 59.22 & (18.33) & $7.34 * * *$ \\
\hline Observations & \multicolumn{2}{|c|}{31688} & \multicolumn{2}{|c|}{27380} & \\
\hline
\end{tabular}


Table 2.

Gender norms index by country

\begin{tabular}{|c|c|c|c|c|c|c|c|c|c|c|c|c|c|c|c|}
\hline \multirow[t]{2}{*}{ Country } & \multicolumn{3}{|c|}{ Gender norms index } & \multicolumn{2}{|c|}{ Attitudes 1} & \multicolumn{2}{|c|}{ Attitudes 2} & \multicolumn{2}{|c|}{ Attitudes 3} & \multicolumn{2}{|c|}{ Attitudes 4} & \multicolumn{2}{|c|}{ Attitudes 5} & \multicolumn{2}{|c|}{ Observations } \\
\hline & Total & Women & Men & Women & Men & Women & Men & Women & Men & Women & Men & Women & Men & Women & Men \\
\hline Peru & 0.09 & 0.10 & 0.08 & 2.66 & 2.66 & 3.20 & 2.91 & 3.16 & 3.08 & 3.22 & 2.99 & 2.31 & 2.31 & 420 & 357 \\
\hline Mexico & -0.02 & -0.03 & -0.01 & 2.55 & 2.55 & 3.03 & 2.85 & 3.01 & 2.91 & 3.09 & 2.92 & 2.30 & 2.35 & 790 & 715 \\
\hline Ecuador & -0.07 & -0.07 & -0.06 & 2.11 & 2.25 & 3.00 & 2.79 & 3.13 & 2.91 & 3.09 & 2.93 & 2.21 & 2.29 & 500 & 427 \\
\hline Mean & 0.00 & 0.00 & 0.00 & 2.45 & 2.49 & 3.06 & 2.85 & 3.08 & 2.95 & 3.12 & 2.94 & 2.28 & 2.32 & 1710 & 1499 \\
\hline
\end{tabular}

Note: Countries are ordered from more to less egalitarian gender norms according to the average value of the gender norms index Higher values for the attitudes measures indicate more egalitarian gender norms. Attitudes of 1 to 5 , correspond to the degree of agreement (with $4=$ strongly disagree) to the following questions: (1) When a mother works for pay, the children suffer (2) On the whole, men make better political leaders than women do (3) A university education is more important for a boy than for a girl (4) On the whole men make better business executives than women (5) Being a housewife is just as fulfilling as working for pay.

Source: last wave of the World Value Survey 
Table 3.

Country-varying factors

\begin{tabular}{lccccc}
\hline Country & $\begin{array}{c}\text { GDP Per } \\
\text { Capita } \\
\text { Growth } \\
\text { (average } \\
\text { annual) }\end{array}$ & $\begin{array}{c}\text { Female } \\
\text { labor force } \\
\text { participation } \\
\text { rate }\end{array}$ & $\begin{array}{c}\text { Masculinity } \\
\text { Ratio }\end{array}$ & $\begin{array}{c}\text { Total } \\
\text { Fertility rate }\end{array}$ & $\begin{array}{c}\text { Population } \\
\text { aged 65 and } \\
\text { older }\end{array}$ \\
\hline Peru & 4.90 & 66.87 & 100.56 & 2.57 & 6.10 \\
Mexico & -1.64 & 42.98 & 96.08 & 2.40 & 5.67 \\
Ecuador & 3.97 & 54.07 & 100.41 & 2.63 & 6.04 \\
\hline
\end{tabular}

Note and sources; GDP per capita growth rates and the female labor force participation rate comes from the World Bank for Peru and Ecuador and INEGI for Mexico. Total fertility rate information comes from the World Bank for Mexico and Ecuador and INEI and World Bank for Peru. Population aged 65 and older information comes from the World Bank for Peru and Mexico and INEC for Ecuador. The values correspond to the average of the years 2007, 2008 and 2009 for Mexico, the average of the years 2008, 2009 and 2010 for Peru and the average of the years 2010, 2011 and 2012 for Ecuador. The masculinity ratio comes from INEI for Peru, INEGI for Mexico and INEC for Ecuador, The values correspond to the average of the years 2005 and 2010 for Mexico, the average of the years 2005 and 2010 for Peru and the average of the years 2007 and 2012 for Ecuador. 
Table 4.

OLS regressions on the time devoted to total work

\begin{tabular}{|c|c|c|c|c|c|c|c|c|}
\hline VARIABLES & $\begin{array}{l}\text { (1) } \\
\text { All }\end{array}$ & $\begin{array}{c}(2) \\
\text { All + GDP } \\
\text { per capita } \\
\text { growth }\end{array}$ & $\begin{array}{c}(3) \\
\text { All }+ \\
\text { Female } \\
\text { labor force }\end{array}$ & $\begin{array}{c}\text { (4) } \\
\text { All }+ \\
\text { Masculinity } \\
\text { ratio }\end{array}$ & $\begin{array}{c}\text { (5) } \\
\text { All }+ \\
\text { fertility rate }\end{array}$ & $\begin{array}{c}(6) \\
\text { All }+ \\
\text { population } \\
65 \text { and older }\end{array}$ & $\begin{array}{c}(7) \\
\text { All }+ \\
\text { country- } \\
\text { varying } \\
\text { factors }\end{array}$ & $\begin{array}{c}(8) \\
\text { All + gender } \\
\text { norms index }+ \\
\text { country varying- } \\
\text { factors }\end{array}$ \\
\hline Woman & $\begin{array}{c}3.918 * * * \\
(0.207)\end{array}$ & $\begin{array}{c}3.919 * * * \\
(0.207)\end{array}$ & $\begin{array}{c}3.915 * * * \\
(0.207)\end{array}$ & $\begin{array}{c}3.912 * * * \\
(0.207)\end{array}$ & $\begin{array}{c}3.922 * * * \\
(0.207)\end{array}$ & $\begin{array}{c}3.905 * * * \\
(0.207)\end{array}$ & $\begin{array}{c}3.909 * * * \\
(0.207)\end{array}$ & $\begin{array}{c}2.510 * * * \\
(0.239)\end{array}$ \\
\hline Primary education & $\begin{array}{c}-2.597 * * * \\
(0.281)\end{array}$ & $\begin{array}{c}-2.615 * * * \\
(0.281)\end{array}$ & $\begin{array}{c}-2.563 * * * \\
(0.281)\end{array}$ & $\begin{array}{c}-2.585^{* * * *} \\
(0.281)\end{array}$ & $\begin{array}{c}-2.626 * * * \\
(0.281)\end{array}$ & $\begin{array}{c}-2.654 * * * \\
(0.281)\end{array}$ & $\begin{array}{c}-2.645 * * * \\
(0.281)\end{array}$ & $\begin{array}{c}-2.583 * * * \\
(0.281)\end{array}$ \\
\hline University education & $\begin{array}{c}-1.022 * * * \\
(0.333)\end{array}$ & $\begin{array}{c}-1.019 * * * \\
(0.333)\end{array}$ & $\begin{array}{c}-1.004 * * * \\
(0.333)\end{array}$ & $\begin{array}{c}-1.003 * * * \\
(0.333)\end{array}$ & $\begin{array}{c}-1.034 * * * \\
(0.333)\end{array}$ & $\begin{array}{c}-1.104 * * * \\
(0.333)\end{array}$ & $\begin{array}{c}-1.059 * * * \\
(0.333)\end{array}$ & $\begin{array}{c}-1.078 * * * \\
(0.333)\end{array}$ \\
\hline Age & $\begin{array}{l}1.646 * * * \\
(0.0639)\end{array}$ & $\begin{array}{l}1.652 * * * \\
(0.0639)\end{array}$ & $\begin{array}{c}1.641 * * * \\
(0.0639)\end{array}$ & $\begin{array}{l}1.650 * * * \\
(0.0639)\end{array}$ & $\begin{array}{l}1.645 * * * \\
(0.0639)\end{array}$ & $\begin{array}{l}1.641 * * * \\
(0.0639)\end{array}$ & $\begin{array}{l}1.642 * * * \\
(0.0639)\end{array}$ & $\begin{array}{l}1.642 * * * \\
(0.0638)\end{array}$ \\
\hline Age squared & $\begin{array}{c}-2.043 * * * \\
(0.0761)\end{array}$ & $\begin{array}{c}-2.049 * * * \\
(0.0762)\end{array}$ & $\begin{array}{c}-2.037 * * * \\
(0.0761)\end{array}$ & $\begin{array}{c}-2.047 * * * \\
(0.0761)\end{array}$ & $\begin{array}{c}-2.041 * * * \\
(0.0761)\end{array}$ & $\begin{array}{c}-2.038 * * * \\
(0.0761)\end{array}$ & $\begin{array}{c}-2.038 * * * \\
(0.0761)\end{array}$ & $\begin{array}{c}-2.040 * * * \\
(0.0760)\end{array}$ \\
\hline No. household members & $\begin{array}{c}-5.793 * * * \\
(0.121)\end{array}$ & $\begin{array}{c}-5.793 * * * \\
(0.121)\end{array}$ & $\begin{array}{c}-5.802 * * * \\
(0.121)\end{array}$ & $\begin{array}{c}-5.812 * * * \\
(0.121)\end{array}$ & $\begin{array}{c}-5.791 * * * \\
(0.121)\end{array}$ & $\begin{array}{c}-5.792 * * * \\
(0.120)\end{array}$ & $\begin{array}{c}-5.802 * * * \\
(0.120)\end{array}$ & $\begin{array}{c}-5.777 * * * \\
(0.120)\end{array}$ \\
\hline No. children $0-4$ & $\begin{array}{c}8.291 * * * \\
(0.215)\end{array}$ & $\begin{array}{c}8.290 * * * \\
(0.215)\end{array}$ & $\begin{array}{c}8.305^{* * * *} \\
(0.215)\end{array}$ & $\begin{array}{c}8.315 * * * \\
(0.215)\end{array}$ & $\begin{array}{c}8.292 * * * \\
(0.215)\end{array}$ & $\begin{array}{c}8.347 * * * \\
(0.214)\end{array}$ & $\begin{array}{c}8.367 * * * \\
(0.214)\end{array}$ & $\begin{array}{c}8.370 * * * \\
(0.214)\end{array}$ \\
\hline No. children 5-12 & $\begin{array}{c}6.784 * * * \\
(0.165)\end{array}$ & $\begin{array}{c}6.780 * * * \\
(0.165)\end{array}$ & $\begin{array}{c}6.796 * * * \\
(0.165)\end{array}$ & $\begin{array}{c}6.797 * * * \\
(0.165)\end{array}$ & $\begin{array}{c}6.777 * * * \\
(0.165)\end{array}$ & $\begin{array}{c}6.841 * * * \\
(0.165)\end{array}$ & $\begin{array}{c}6.847 * * * \\
(0.165)\end{array}$ & $\begin{array}{c}6.829 * * * \\
(0.165)\end{array}$ \\
\hline No. children $13-17$ & $\begin{array}{c}4.712 * * * \\
(0.187)\end{array}$ & $\begin{array}{c}4.703 * * * \\
(0.187)\end{array}$ & $\begin{array}{c}4.732 * * * \\
(0.187)\end{array}$ & $\begin{array}{c}4.726 * * * \\
(0.187)\end{array}$ & $\begin{array}{c}4.713 * * * \\
(0.187)\end{array}$ & $\begin{array}{c}4.759 * * * \\
(0.187)\end{array}$ & $\begin{array}{c}4.786^{* * * *} \\
(0.187)\end{array}$ & $\begin{array}{c}4.752 * * * \\
(0.186)\end{array}$ \\
\hline No. elderly 70 or more & $\begin{array}{c}2.623 * * * \\
(0.331)\end{array}$ & $\begin{array}{c}2.611 * * * \\
(0.332)\end{array}$ & $\begin{array}{c}2.629 * * * \\
(0.331)\end{array}$ & $\begin{array}{c}2.608 * * * \\
(0.331)\end{array}$ & $\begin{array}{c}2.638 * * * \\
(0.331)\end{array}$ & $\begin{array}{c}2.602 * * * \\
(0.331)\end{array}$ & $\begin{array}{c}2.607 * * * \\
(0.331)\end{array}$ & $\begin{array}{c}2.619 * * * \\
(0.330)\end{array}$ \\
\hline Presence of partner & $\begin{array}{c}1.340 * * * \\
(0.249)\end{array}$ & $\begin{array}{c}1.320 * * * \\
(0.249)\end{array}$ & $\begin{array}{c}1.354 * * * \\
(0.249)\end{array}$ & $\begin{array}{c}1.325 * * * \\
(0.249)\end{array}$ & $\begin{array}{c}1.333 * * * \\
(0.249)\end{array}$ & $\begin{array}{c}1.275 * * * \\
(0.249)\end{array}$ & $\begin{array}{c}1.257 * * * \\
(0.249)\end{array}$ & $\begin{array}{c}1.249 * * * \\
(0.248)\end{array}$ \\
\hline No. men in labor market & $\begin{array}{c}4.844 * * * \\
(0.186)\end{array}$ & $\begin{array}{c}4.843 * * * \\
(0.186)\end{array}$ & $\begin{array}{c}4.849 * * * \\
(0.186)\end{array}$ & $\begin{array}{c}4.856 * * * \\
(0.186)\end{array}$ & $\begin{array}{c}4.854 * * * \\
(0.186)\end{array}$ & $\begin{array}{c}4.872 * * * \\
(0.186)\end{array}$ & $\begin{array}{c}4.882 * * * \\
(0.186)\end{array}$ & $\begin{array}{c}4.901 * * * \\
(0.185)\end{array}$ \\
\hline No. women in labor market & $\begin{array}{c}9.651 * * * \\
(0.163)\end{array}$ & $\begin{array}{c}9.632 * * * \\
(0.163)\end{array}$ & $\begin{array}{c}9.655 * * * \\
(0.163)\end{array}$ & $\begin{array}{c}9.634 * * * \\
(0.163)\end{array}$ & $\begin{array}{c}9.661 * * * \\
(0.163)\end{array}$ & $\begin{array}{c}9.538 * * * \\
(0.163)\end{array}$ & $\begin{array}{c}9.508 * * * \\
(0.163)\end{array}$ & $\begin{array}{c}9.406 * * * \\
(0.163)\end{array}$ \\
\hline Rural residence & $\begin{array}{c}1.820 * * * \\
(0.229)\end{array}$ & $\begin{array}{c}1.816^{* * * *} \\
(0.229)\end{array}$ & $\begin{array}{c}1.851 * * * \\
(0.229)\end{array}$ & $\begin{array}{c}1.825^{* * * *} \\
(0.229)\end{array}$ & $\begin{array}{c}1.761 * * * \\
(0.230)\end{array}$ & $\begin{array}{c}1.846 * * * \\
(0.229)\end{array}$ & $\begin{array}{c}1.884 * * * \\
(0.231)\end{array}$ & $\begin{array}{c}1.568 * * * \\
(0.232)\end{array}$ \\
\hline Indigenous & $\begin{array}{c}3.719 * * * \\
(0.350)\end{array}$ & $\begin{array}{c}3.813 * * * \\
(0.351)\end{array}$ & $\begin{array}{c}3.653 * * * \\
(0.351)\end{array}$ & $\begin{array}{c}3.688 * * * \\
(0.350)\end{array}$ & $\begin{array}{c}3.628 * * * \\
(0.353)\end{array}$ & $\begin{array}{c}3.821 * * * \\
(0.350)\end{array}$ & $\begin{array}{c}3.883 * * * \\
(0.356)\end{array}$ & $\begin{array}{c}3.472 * * * \\
(0.358)\end{array}$ \\
\hline GDP per capita growth rate & & $\begin{array}{c}1.142 * * * \\
(0.356)\end{array}$ & & & & & $\begin{array}{c}4.235^{* * * *} \\
(0.945)\end{array}$ & $\begin{array}{c}3.518 * * * \\
(0.948)\end{array}$ \\
\hline Female labor force participation & & & $\begin{array}{c}1.267 * * * \\
(0.425)\end{array}$ & & & & $\begin{array}{c}4.373 * * * \\
(0.865)\end{array}$ & $\begin{array}{c}3.397 * * * \\
(0.869)\end{array}$ \\
\hline Masculinity ratio & & & & $\begin{array}{c}-0.304 * * * \\
(0.0623)\end{array}$ & & & $\begin{array}{l}0.269 * * \\
(0.137)\end{array}$ & $\begin{array}{c}0.127 \\
(0.137)\end{array}$ \\
\hline Fertility rate & & & & & $\begin{array}{c}1.824 * * * \\
(0.543)\end{array}$ & & $\begin{array}{c}1.654 * * * \\
(0.542)\end{array}$ & $\begin{array}{c}2.323 * * * \\
(0.546)\end{array}$ \\
\hline Population aged 65 and older & & & & & & $\begin{array}{c}1.143 * * * \\
(0.107)\end{array}$ & $\begin{array}{c}1.147 * * * \\
(0.107)\end{array}$ & $\begin{array}{l}1.269 * * * \\
(0.109)\end{array}$ \\
\hline Gender norms index & & & & & & & & $\begin{array}{c}11.96 * * * \\
(1.069)\end{array}$ \\
\hline Peru & $\begin{array}{c}2.051 * * * \\
(0.284)\end{array}$ & $\begin{array}{c}0.982 * * \\
(0.438)\end{array}$ & $\begin{array}{c}-14.15 * * * \\
(5.439)\end{array}$ & $\begin{array}{c}2.105^{* * * *} \\
(0.284)\end{array}$ & $\begin{array}{c}2.050 * * * \\
(0.284)\end{array}$ & $\begin{array}{c}2.635 * * * \\
(0.287)\end{array}$ & $\begin{array}{c}-57.31 * * * \\
(11.86)\end{array}$ & $\begin{array}{c}-45.19 * * * \\
(11.92)\end{array}$ \\
\hline Mexico & $\begin{array}{c}1.011 * * * \\
(0.221)\end{array}$ & $\begin{array}{c}7.387 * * * \\
(2.006)\end{array}$ & $\begin{array}{c}15.07 * * * \\
(4.714)\end{array}$ & $\begin{array}{l}-0.378 \\
(0.355)\end{array}$ & $\begin{array}{c}1.412 * * * \\
(0.252)\end{array}$ & $\begin{array}{c}2.106 * * * \\
(0.239)\end{array}$ & $\begin{array}{c}75.86 * * * \\
(14.95)\end{array}$ & $\begin{array}{c}60.57 * * * \\
(15.02)\end{array}$ \\
\hline Constant & $\begin{array}{c}33.91 * * * \\
(1.305)\end{array}$ & $\begin{array}{c}29.30 * * * \\
(1.947)\end{array}$ & $\begin{array}{l}-34.53 \\
(22.97)\end{array}$ & $\begin{array}{c}64.42 * * * \\
(6.386)\end{array}$ & $\begin{array}{c}29.16^{* * * *} \\
(1.910)\end{array}$ & $\begin{array}{c}26.47 * * * \\
(1.480)\end{array}$ & $\begin{array}{c}-258.2 * * * \\
(61.74)\end{array}$ & $\begin{array}{c}-224.2 * * * \\
(61.83)\end{array}$ \\
\hline R-squared & 0.128 & 0.129 & 0.129 & 0.129 & 0.129 & 0.130 & 0.131 & 0.133 \\
\hline Observations & 59,068 & 59,068 & 59,068 & 59,068 & 59,068 & 59,068 & 59,068 & 59,068 \\
\hline
\end{tabular}

Note: Robust standard errors in parentheses. *Significant at the $90 \%$ level, **at the $95 \%$ level, *** at the $99 \%$ level. Demographic weights by Katz and Murphy (1992), Ecuador is the reference country. 
Table 5.

OLS regressions on the time devoted to total work, couples only sample

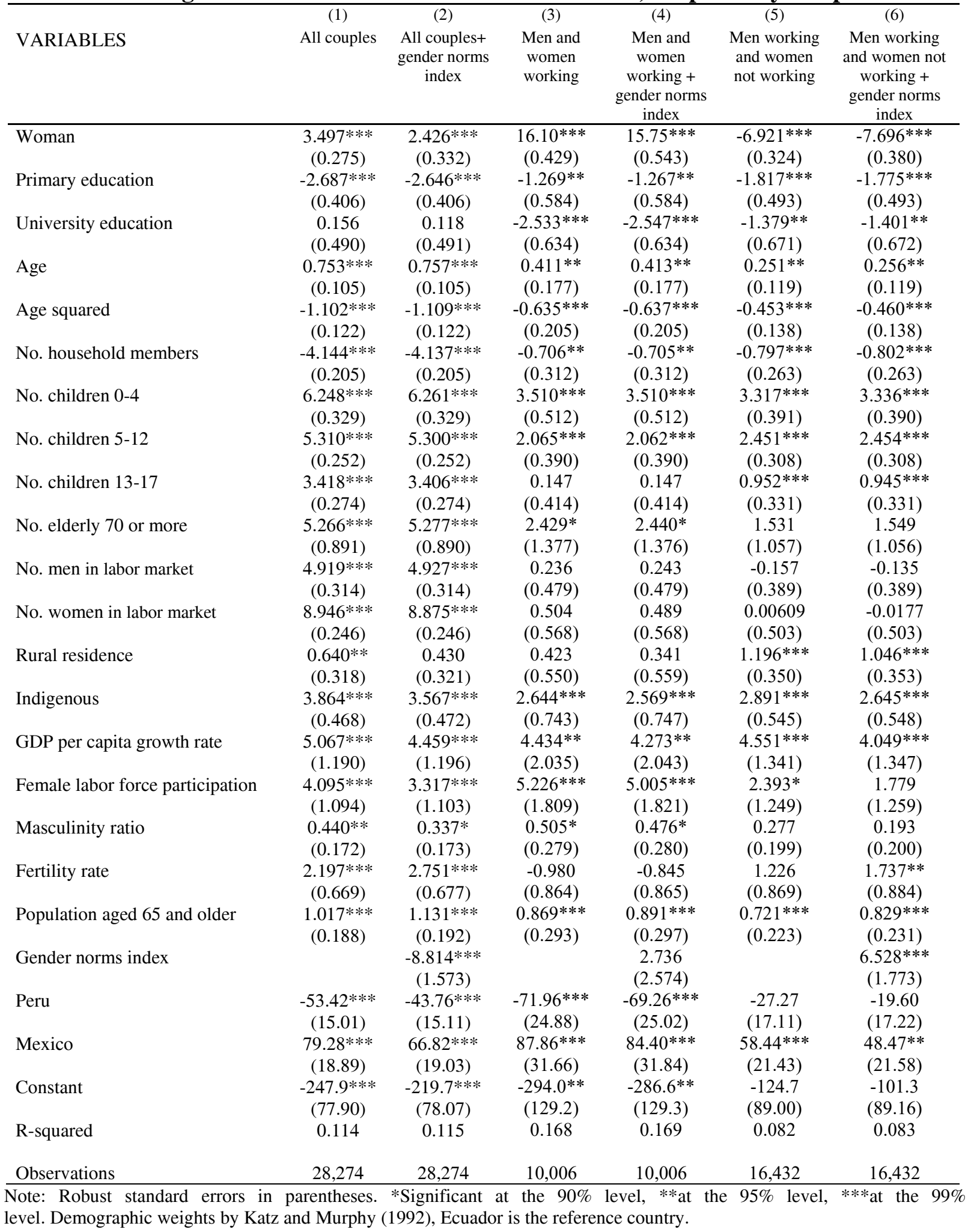

